Palaeoecology of a Well-Preserved Crinoid Colony from the Silurian Rochester Shale in Ontario

Carlton E. Brett James D. Eckert

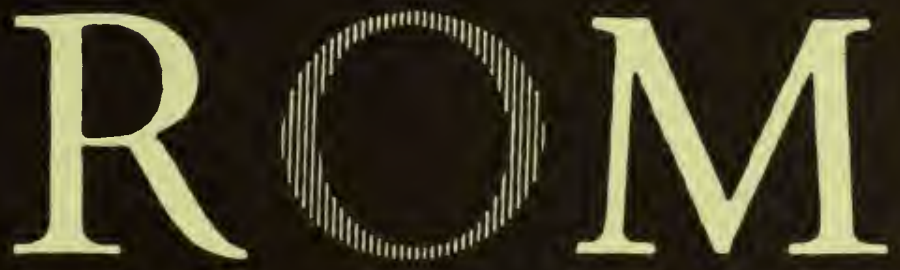




\section{ROYAL ONTARIO MUSEUM LIFE SCIENCES PUBLICATIONS INSTRUCTIONS TO AUTHORS}

Authors are to prepare their manuscripts carefully according to the following instructions. Failure to do so will result in the manuscript's being returned to the author for revision. All manuscripts are considered on the understanding that if accepted they will not be offered for publication elsewhere.

1. GENERAL Papers for publication are accepted from ROM staff members, Research Associates, or from researchers reporting on work done with ROM collections. In exceptional cases,monographic works on the flora and/or fauna of Ontario will be considered for publication by authors not affiliated with the ROM. Authors are expected to write clearly and concisely, and to omit all material not essential for an understanding of the main theme of the paper.

2. FORMAT Manuscripts are to be typed double-spaced (including captions, synonomies, literature cited, and tables) on 11" $\times 81 / 2$ " paper with a $1 \frac{1 / 2}{2}$ " margin on all sides. Three xerox copies are to be submitted to the Chairman of the Editorial Board, and the original retained by the author(s). A separate sheet is to be submitted giving author(s) names, affiliation, title of publication, series in which it is to appear, number of typed pages, number of tables, and number of figures. Manuscripts should normally be organized in the following order: Table of Contents, Abstract, Introduction, Materials and Methods, Results, Discussion, Conclusions, Summary (if paper is long), Acknowledgements, Literature Cited, and Appendices. Authors are encouraged to include foreign language translations of the Summary where appropriate. Headings of sections are to be left-justified to the text margin. The first line of the first paragraph in each new section should not be indented. Text-figures are referred to as "Fig. 1". Literature cited in the text is in the form "Jones (1972)" or "(Jones, 1972)" or "(Smith, 1960:71-79, fig. 17)".

3. STANDARD SOURCES The primary source for decisions on format and style is A Guide for Contributors and Editors of ROM Life Sciences Publications, available from the Chairman of the Editorial Board. Otherwise, consult CBE (AIBS) Style Manual (3rd Edition). Other standard sources are as follows: for English spelling (Concise Oxford Dictionary), for Canadian place names and coordinates (Gazetteer of Canada), and for spelling of geographic names (Times [London] Atlas).

4. ABSTRACT All papers are preceded by a short and factual abstract, about 3 per cent as long as the text, but not longer than 400 words. The abstract is to be followed by four to six keywords enclosed in brackets.

5. TAXONOMY The name of a taxon is given in full in headings, where it appears for the first time, or when the name begins a paragraph. Use authority and date if appropriate, with first mention of each taxon and not thereafter. Taxonomic papers follow the layout in Life Sciences Contribution 99, particularly the synonomies.

6. LITERATURE CITED References in the text cite author and date and are enclosed in parentheses (Smith, 1978). Complete references are listed in alphabetical order by author at the end of the paper. When there are two or more citations for an author, the works are listed chronologically. Names of journals are not abbreviated. Consult Life Sciences Contributions beginning with 117 for correct bibliographic form.

7. TABLES All tables are numbered consecutively in arabic numerals in numerical order of their first mention in the text. Mark the appropriate text location of each table with a marginal notation. Each table is typed on a separate sheet. Avoid footnotes etc., to tables by building them into the title.

8. FIGURES All figures are numbered consecutively in arabic numerals. Component photographs or drawings are labelled sequentially in upper case letters. Mark the appropriate text location of each figure with a marginal notation. The intended reduction for figures is ideally one and a half to two times. All labelling on figures is in blue pencil and not inked or letraset. Halftones must be photographic prints of high contrast on glossy paper. Authors are to submit $10^{\prime \prime} \times 8$ " copies with the MS and retain originals until they are requested. Figure captions are to appear grouped together on a separate page at the end of the MS. 
LIFE SCIENCES CONTRIBUTIONS

ROYAL ONTARIO MUSEUM

NUMBER 131

CARLTON E. BRETT JAMES D. ECKERT

\section{Palaeoecology of a Well-Preserved Crinoid Colony from the Silurian Rochester Shale in Ontario}




\section{ROYAL ONTARIO MUSEUM PUBLICATIONS IN LIFE SCIENCES}

The Royal Ontario Museum publishes three series in the Life Sciences.

LIFE SCIENCES CONTRIBUTIONS, a numbered series of original scientific publications including monographic works.

LIFE SCIENCES OCCASIONAL PAPERS, a numbered series of original scientific publications, primarily short and usually of taxonomic significance.

LIFE SCIENCES MISCELLANEOUS PUBLICATIONS, an unnumbered series of publications of varied subject matter and format.

All manuscripts considered for publication are subject to the scrutiny and editorial policies of the Life Sciences Editorial Board, and to review by persons outside the Museum staff who are authorities in the particular field involved.

\section{LIFE SCIENCES EDITORIAL BOARD}

Senior Editor: C. McGOWAN

Editor: P.H. von BITTER

Editor: R. WINTERBOTTOM

CARLTON E. BRETT is Professor in the Department of Geological Sciences, University of Rochester, Rochester, New York 14627 (Tel.: 716 275-2408).

JAMES D. ECKERT is a former Graduate Student in the Department of Geology, University of Toronto.

\section{Canadian Cataloguing in Publication Data}

Brett, Carlton Elliot.

Palaeoecology of a well-preserved crinoid colony from the Silurian Rochester shale in Ontario

(Life sciences contributions, ISSN 0384-8159 ; no. 131)

Bibliography: $p$.

ISBN 0-88854-281-X

1. Crinoidea, Fossil. 2. Paleontology-Silurian.

3. Paleontology - Ontario-Sixteen Mile Creek (Niagara).

I. Eckert, James D., 1952- II. Royal Ontario Museum.

1II. Title. IV. Series

QE782.B73 563.91'0971351 C82-094054-2

Publication date: 19 January 1982

ISBN 0-88854-281-X

ISSN 0384-8159

(C) The Royal Ontario Museum, 1982

100 Queen's Park, Toronto, Canada M5S 2C6

PRINTED AND BOUND IN CANADA AT THE ALGER PRESS 


\title{
Palaeoecology of a Well-Preserved Crinoid Colony from the Silurian Rochester Shale in Ontario
}

\begin{abstract}
An exceptionally well-preserved assemblage of crinoids and other fossils is described from the Rochester Shale (Upper Silurian, Wenlockian) of Ontario. These crinoids have retained complete crowns, columns, and holdfasts and are preserved essentially in life position, indicating rapid destruction and anastrophic burial of a level, mud-bottom community. The crinoid colony was numerically dominated by the minute inadunate Homocrinus parvus Hall, which occurs in densities of 1500 specimens $/ \mathrm{m}^{2}$; these crinoids possess stems more than $100 \mathrm{~mm}$ long. Specimens of Eucalyptocrinites caelatus (Hall) from this assemblage exhibit shorter columns (60 to $100 \mathrm{~mm}$ ) and dendritic radices. Columns of this species were utilized as attachment substrates by other organisms such as favositids, brachiopods, and other crinoids. Complete juvenile specimens of Dimerocrinites spp. occur attached to the Eucalyptocrinites columns by coiled distal stem termini.

This assemblage represents a local dense aggregation of organisms on an otherwise sparsely populated sea floor. Soft, muddy bottoms and high rates of sedimentation may have inhibited settlement of the sea floor by most low-level suspension-feeding organisms. However, once "pioneer" individuals of crinoids became established they permitted colonization by various other organisms.

Conditions favourable for the preservation of complete crinoids occur most frequently in a limited range of depositional environments, that is, low energy, mud-bottom areas below normal wave base but within reach of storm waves. Consequently many of the bestpreserved crinoid assemblages are probably derived from similar biotopes and represent rather unusual mud-bottom, rheophobic associations.
\end{abstract}




\section{Introduction}

Echinoderms are notoriously susceptible to post-mortem disarticulation (Ruhrmann, 1971; Meyer, 1971; Liddell, 1975, and in preparation; Kier, 1977). The occurrence of large numbers of completely articulated fossil crinoids is extremely rare and is a reliable indication of catastrophic annihilation and burial of a benthic community (Rosenkranz, 1971; Lane, 1973). However, examples of such exceptionally preserved crinoid assemblages (crinoid Konservat-lagerstätten, sensu Seilacher, 1970) occur sporadically in the geologic record and they provide significant insights into the morphology and life habits of ancient pelmatozoans and associated organisms (Lane, 1963, 1972, 1973; Rosenkranz, 1971; Hagdorn, 1978). Since these assemblages often approximate in situ remains of marine communities, they are also of palaeoecologic significance. Detailed analyses of crinoid lagerstätten can serve as models for the interpretation of associated, and far more numerous, assemblages of disarticulated crinoid remains. This paper focuses on one such lagerstätten occurrence.

During the spring of 1976 an assemblage of exceptionally well-preserved crinoids was discovered near the base of the Rochester Shale (Upper Silurian, Wenlockian) near Sixteen Mile Creek, Jordan, Ontario. Excavation at this site permitted collection of slabs, now housed at the Royal Ontario Museum, which show complete skeletal structure of the crinoids Eucalyptocrinites caelatus (Hall) and Dimerocrinites spp. In addition, numerous well-preserved individuals of Homocrinus parvus Hall, and other fossils are preserved in a closely packed aggregation.

The Sixteen Mile Creek crinoid occurrence appears to be nearly as good an example of an in situ fossil assemblage as is ever seen in the geologic record. Apart from the non-preservable soft-bodied organisms, this assemblage is inferred to be a rather accurate representation of one type of Silurian level, mud-bottom community.

\section{Materials and Methods}

Well-preserved crinoids and a few associated fossils occur in a single horizon $1.4 \mathrm{~m}$ above the base of the Rochester Shale in a west-facing bank of Sixteen Mile Creek, near Jordan, Lincoln Co., Ontario (NTS Niagara 30M/3W; Fig. 1). The horizon was initially recognized when four complete crowns of Eucalyptocrinites were discovered, partially weathered-out and protruding from the surface of the outcrop. Subsequent excavation of approximately $3.7 \mathrm{~m}^{2}$ of this horizon revealed two small clusters of complete Eucalyptocrinites and other fossils, each occupying about $1000 \mathrm{~cm}^{2}$ and separated by about $2.3 \mathrm{~m}$. These crinoid-rich patches were surrounded by spaces of apparently unfossiliferous shale. Most of the data pertaining to the Homocrinus-Eucalyptocrinites horizon are derived from a detailed examination of a large slab measuring $52 \mathrm{~cm}$ by $24 \mathrm{~cm}$, which is in the Royal Ontario Museum (ROM 35832; Fig. 2). This slab was collected intact by channelling of the surrounding shale with chisels. The remainder of this colony and the second, smaller Eucalyptocrinites patch, were collected as isolated specimens or obtained on small slabs of shale. Further excavation at the Sixteen Mile Creek site would be extremely difficult owing 


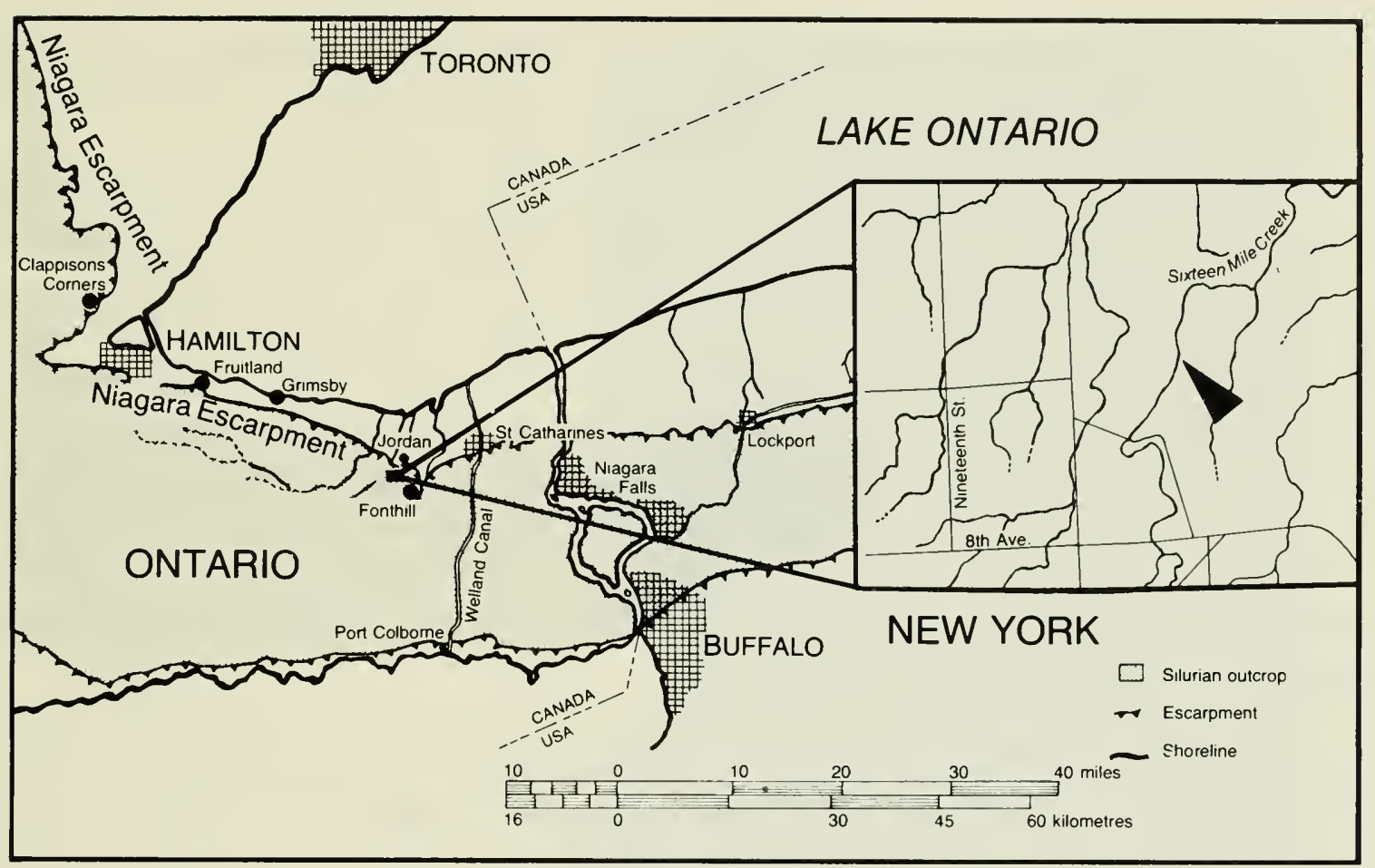

Fig. 1 Locality map for Sixteen Mile Creek crinoid occurrence; inset shows details of the Sixteen Mile Creek area (arrow indicates collecting site). Map reference NTS (National Topographic Series) Niagara $30 \mathrm{M} / 3 \mathrm{~W}$.

to the steepness of the bank and the thickness of overburden which must be removed to clear the crinoid horizon. Neither of the two crinoid patches appeared to continue back into the unexcavated areas beneath the bank, although some Homocrinus specimens may have been overlooked in the field.

The surfaces of the shale slabs were carefully prepared using an air-abrasive unit and dolomite powder. A thin layer of shale matrix coating the surface of the slabs was removed, revealing abundant Homocrinus and complete stem and root systems of many of the Eucalyptocrinites specimens. The area of the large slab was obtained from a traced outline, and abundances of various fossil taxa within the aggregation were determined.

\section{Stratigraphic Setting}

Outcrops of Rochester Shale along Sixteen Mile Creek are discontinuous and a complete measured section cannot be made at this locality. However, the lower third of the Rochester Shale in this outcrop differs markedly from the same interval in exposures both east and west of the Jordan area (see Bolton, 1957) in possessing a very high proportion of homogeneous, sparsely fossiliferous shale. Bryozoan-rich limestones and fossiliferous shales are restricted to the basal $0.5 \mathrm{~m}$ of the shale; two 
thin calcisiltite bands occur, interbedded with barren shale, the highest of which is about $0.6 \mathrm{~m}$ above the Irondequoit. The main crinoid horizon occurs within an interval of otherwise sparsely fossiliferous, dark grey, silty shale.

Three additional well-preserved crinoid specimens were obtained from higher levels during the excavation of the main crinoid-bearing horizon. Two crowns of Asaphocrinus ornatus (Hall), one with a complete stem and holdfast attached to a brachiopod, were collected on a small slab of shale containing brachiopods and bryozoans about $2.16 \mathrm{~m}$ above the base of the Rochester Shale. A specimen of Dendrocrinus longidactylus Hall with a calyx and a nearly complete stem was also collected on a slab of silty shale at intermediate level, $1.68 \mathrm{~m}$ above the Irondequoit Limestone. Aside from these isolated small occurrences the rock both overlying and underlying the Eucalyptocrinites horizon proved to be barren. Although the top of the bank exposure is covered, there is at least $3 \mathrm{~m}$ of similar lithology overlying the highest Asaphocrinus crinoid-bearing bed.

The entire Rochester Formation is continuously exposed in a small stream gully about $1 \mathrm{~km}$ east of Sixteen Mile Creek. Here the lower Rochester resembles that at Sixteen Mile Creek; fossiliferous limestones are again restricted to the base of the formation and the entire remainder of the lower Rochester is both unfossiliferous and lacking in interbeds of any sort. This is the only exposure east of Grimsby, Ontario, at which the "Bryozoa Beds" (Grabau, 1901)—-thin biomicrites marking the top of the lower Rochester member-are completely missing.

A high proportion of barren shale in these two outcrops is anomalous with respect to the majority of exposures along the Niagara Escarpment in Ontario, which contain abundant fossiliferous horizons up to $3 \mathrm{~m}$ above the base and, again, at about 6 to $8 \mathrm{~m}$. However, a large proportion of unfossiliferous shale and the virtual disappearance of bryozoan-rich beds is characteristic of outcrops only a few kilometres south of the main escarpment in the Fonthill Reentrant and in the southern end of Niagara Gorge (Fig. 1). Thus, the barren lower Rochester around Sixteen Mile Creek can be interpreted as a local northward extension of the "barren" mudstone facies which apparently existed immediately south of a "Bryozoan Belt" that normally coincides with the present escarpment edge (Brett, 1978c). The apparent northward deflection of the "Bryozoan Belt" in the Jordan, Ontario, area may be associated with a local thickening of the Rochester Shale in the subsurface south of this area around Port Colborne, Ontario. Both phenomena may be attributed to higher rates of fine-grained terrigenous sediment relative to surrounding areas, owing to a local depression of the sea floor or to a persistent offshore current.

The shale at Jordan appears somewhat siltier than that of most Rochester Shale outcrops. The shale overlying the main crinoid horizon shows distinct laminae of siltand clay-sized particles. Discrete calcisiltite bands are lacking in higher portions of the lower member of the Rochester Shale; however, the shales are highly calcareous, suggesting an input of carbonate sediment.

No fossiliferous horizon corresponding to the Eucalyptocrinites bed could be located at an equivalent position in nearby outcrops; thus, this was probably a localized occurrence. 


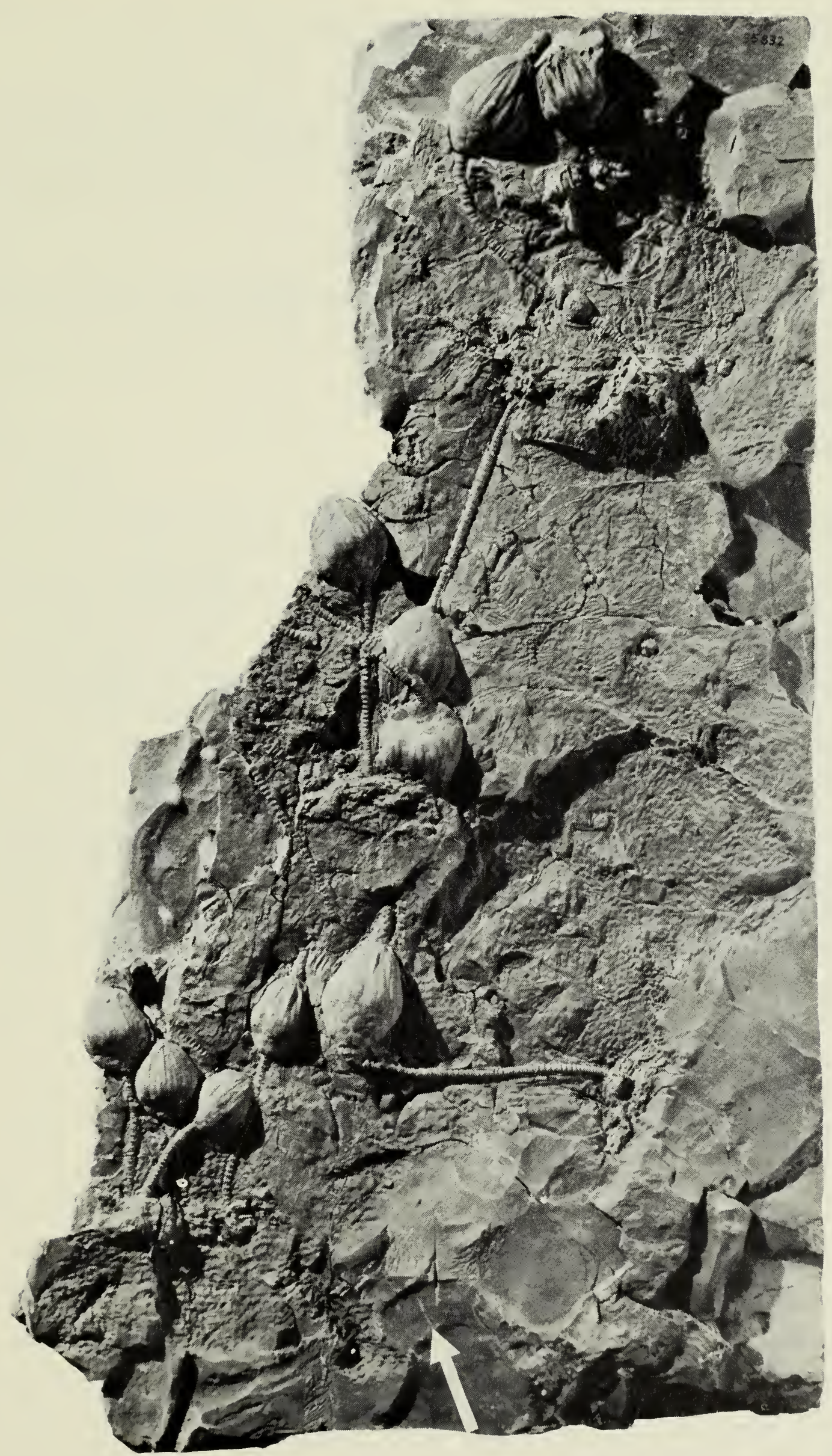

Fig. 2 Overall view of large slab of Rochester Formation containing 10 well-preserved specimens of Eucalyptocrinites caelatus (Hall); note general alignment of specimens; arrow on slab near bottom of page indicates north direction. RoM 35832, $\times 0.35$. 


\section{Faunal Composition and Autecology of Fossils}

Examination of a large surface area of the crinoid-bearing horizon yielded a total fauna of 10 species of fossils, numerically dominated by the crinoid Homocrinus parvus Hall. Fossil density data for the large slab assemblage are summarized in Table 1.

Table 1 Data on Eucalyptocrinites-Homocrinus slab assemblage, Sixteen Mile Creek, Jordan, Ontario

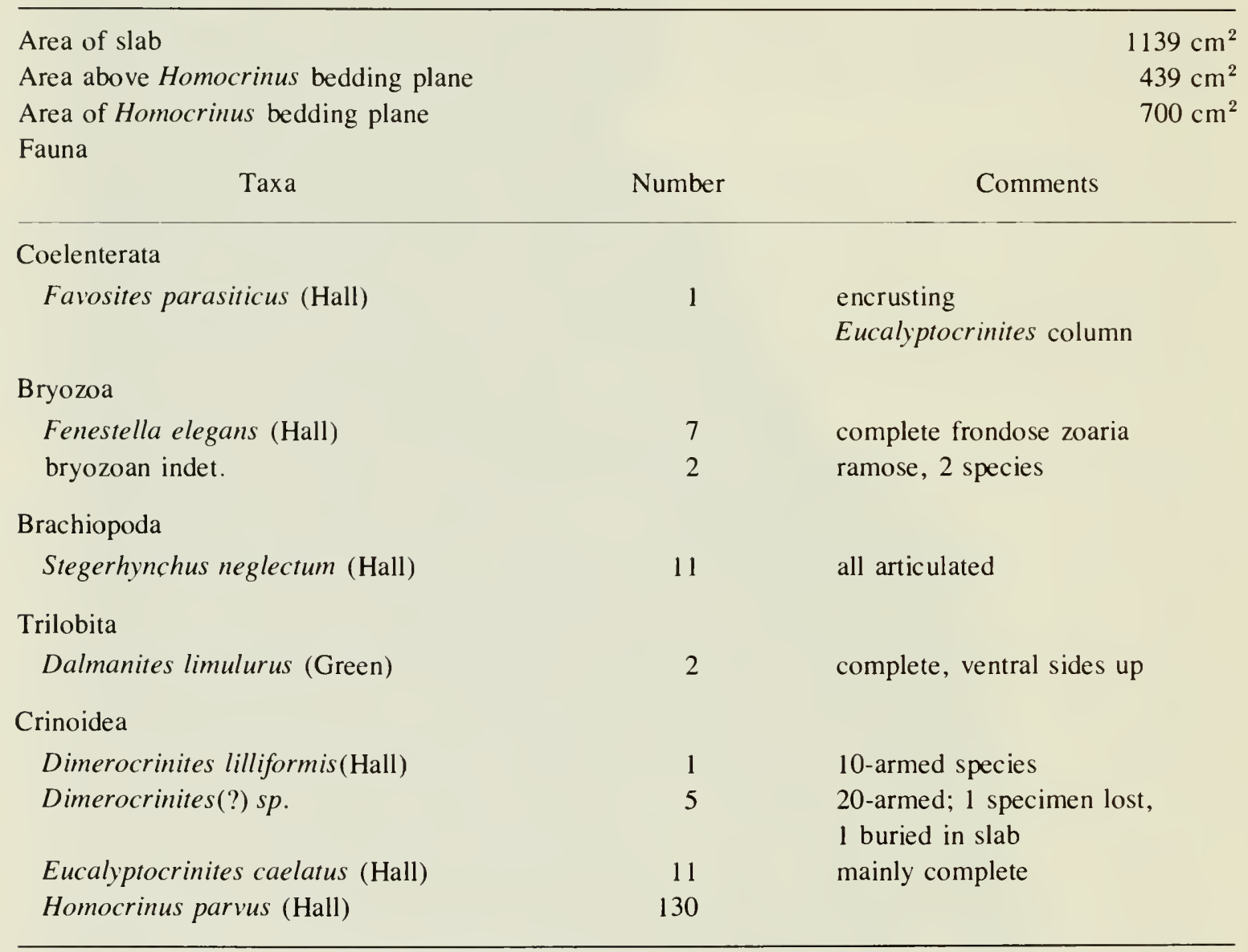

\section{Tabulata}

Two specimens of the tabulate coral Favosites parasiticus (Hall) were observed. Both occurred as small (diameter about $10 \mathrm{~mm}$ ), symmetrical colonies attached to the columns of two Eucalyptocrinites specimens (Figs. 3, 4A). Corals evidently grew on the upright stems of living crinoids since they are symmetrically developed around the column. There was no observable reaction on the part of the crinoids (e.g., secretion of secondary stereom). Favosites parasiticus has previously been observed on columns of Eucalyptocrinites crassus (Hall) from the Waldron Shale of Indiana (Hall, 1881) and on stems of Caryocrinites from the Rochester Shale of New York (Hall, 1852). The persistent association of this tabulate coral with well-preserved (i.e., live at time of coral attachment) pelmatozoans suggests substrate selectivity by this tabulate species. 


\section{Bryozoa}

Several well-preserved frondose zoaria of Fenestella sp. were observed on the prepared surface of the large slab. All were lying flat and were strongly compressed, but they are not fragmented. One possesses a single, small cemented crinoid holdfast, perhaps belonging to Homocrinus. In addition, two small ramose trepostomatous bryozoans occur on the slab.

Fenestrate bryozoans were also abundant on the Asaphocrinus-bearing slab collected higher in the section. Bryozoans are probably somewhat commoner than recorded as they are lying flat on the slab beneath Homocrinus and other crinoids. Portions of the surface were not completely cleared, to prevent damage to the Homocrinus specimens.

\section{Brachiopoda}

Brachiopods are represented on the large slab by a single species of rhynchonellid tentatively identified as Stegerhynchus neglectum (Hall). The 11 specimens are completely articulated, tightly closed, and similar in size. Most are preserved lying on either the pedicle or brachial valve but the beaks in most cases are closely appressed to other objects. These brachiopods are closely associated with the stems and root systems of Eucalyptocrinites (Fig. 3). However, in no case were the roots observed to be centred on rhynchonellid brachiopods; rather the Stegerhynchus appear to have been pedically attached to exposed portions of the crinoid stems or roots. Similar beak-down orientations (interpreted as life positions) have been observed in other rhynchonellid brachiopods (Richards, 1972).

Stegerhynchus specimens were also obtained from a layer a few centimetres above the crinoid bed and thus were not exclusively associated with this crinoid patch. Stegerhynchus as well as Leptaena was found in the higher Asaphocrinus-bearing slab.

\section{Trilobita}

Two complete exoskeletons of Dalmanites limulurus (Green) occur in inverted orientations on the surface of the large slab (Fig. 4C). Both are approximately $25 \mathrm{~mm}$ long and are complete except for the hypostomes. Aside from these, no other trilobites were present.

\section{Crinoidea}

The slab assemblage is most unusual for lower Rochester fossil occurrences in having such a high density of crinoids. A total of 148 specimens belonging to four species was counted in an area of $700 \mathrm{~cm}^{2}$ on the large slab; this corresponds to a density of 2114 specimens $/ \mathrm{m}^{2}$. The preservation of all specimens is equally good, suggesting that all were living together at the time of burial. Density in this patch far exceeds the maximum "high density crinoid garden" reported by Brower (1973). However, the 
biomass of crinoids in this community was probably not as high as that of other reported occurrences (e.g., Lane, 1973; Brower, 1973) since most of the observed crinoids were relatively minute specimens of Homocrinus parvus Hall (Fig. 4D).

At least 130 calyces of Homocrinus were counted on the prepared portion of the slab; much of the surface is covered with the delicate stems and arms of these crinoids. Tangled masses of stems occur in the vicinity of Eucalyptocrinites radices and some Homocrinus stems may be coiled on the stems of the larger crinoids (Fig. 4C). The high density of specimens appears to continue to the broken edges of the slab and so it is reasonable to assume that Homocrinus covered areas of the sea bottom beyond the immediate vicinity of clusters of Eucalyptocrinites. Specimens were also observed on smaller Eucalyptocrinites-bearing slabs from the second patch. Unfortunately, Homocrinus specimens were virtually invisible on unprepared surfaces owing to a thin coating of clay matrix, thus the total extent of Homocrinus patches on the bedding plane is unknown. The broken edge of the slab reveals that the crinoids occurred through an interval of 1 to $2 \mathrm{~cm}$ of shale so that the total original density may have been 50 to 100 per cent higher than that recorded above.

Specimens of Homocrinus are invariably preserved with arms and long sections of the stem intact. The longest section of stem is in excess of $100 \mathrm{~mm}$ long and is incomplete, lacking the calyx.

Considering the extreme abundance of the Homocrinus specimens it is paradoxical that only a single small holdfast was obtained. Minute attachment discs, thought to belong to Homocrinus, are common in the Lockport Homocrinus beds. Possibly the holdfasts of these crinoids occur attached to small objects at a level slightly below the cleaned surface of the slab.

Complete specimens of the camerate crinoid Eucalyptocrinites caelatus (Hall) are the most conspicuous element of the Sixteen Mile Creek crinoid assemblages (Figs. $3,4 \mathrm{~B}$ ). Ten specimens are present on the $700 \mathrm{~cm}^{2}$ area of the large slab; an additional four crowns were obtained from the periphery of this area, yielding a total density of 14 individuals in an area of about $100 \mathrm{~cm}^{2}$. The second cluster produced 10 Eucalyptocrinites specimens. These are interpreted as in situ crinoids and suggest intraspecific aggregations of Eucalyptocrinites, as in many other echinoderms.

Fig. 3 Detail of ROM 35832 A-F. Specimens of Eucalyptocrinites caelatus and Dimerocrinites spp. Larger Eucalyptocrinites specimen (A) exhibits elongate anal chimney, complete column, and radix holdfast. A specimen of Favosites parasiticus Hall and at least three dimerocrinitid crinoids are attached to the column of this individual. Note that two species of dimerocrinitids are present; the lowest crown (E) is a 10-armed form, Dimerocrinites cf. D. lilliformis (Hall), the other two (C, D) belong to an undescribed 20-armed form, Dimerocrinites(?) sp. The smaller Eucalyptocrinites specimen shows imperfect preservation, note partial collapse of column. Also present on this portion of the slab are three rhynchonellid brachiopods, Stegerhynchus sp., numerous threadlike columns and crowns of Homocrinus parvus Hall, and the column and root of a third Eucalyptocrinites individual $(\mathrm{F}), \times 1.25$. 


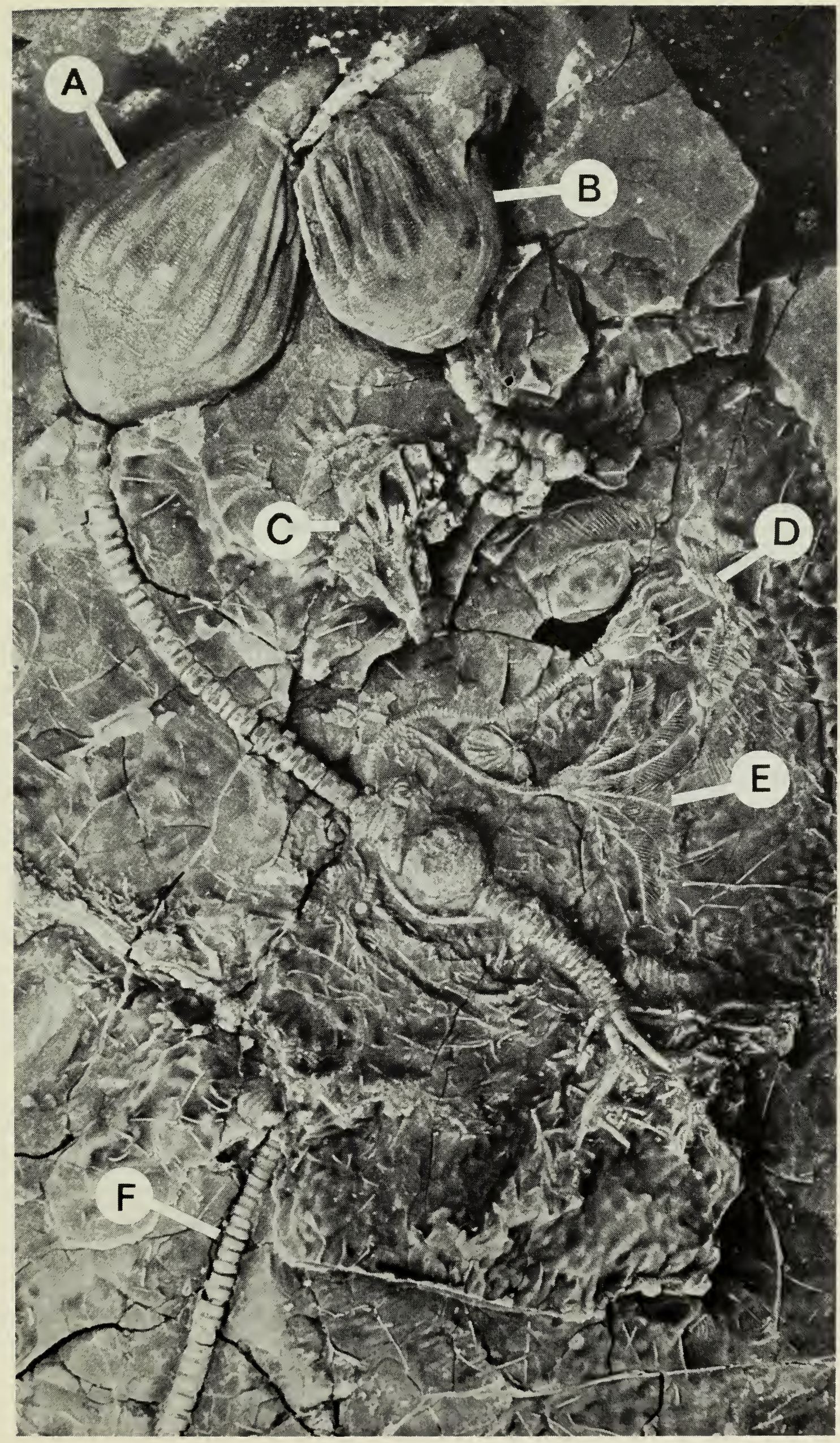


Preservation of the Eucalyptocrinites is exceptional; this is undoubtedly the best-preserved assemblage of these crinoids ever collected. All specimens consist of completely uncrushed to slightly compressed crowns, with long anal chimneys preserved intact (Fig. 4B); the arms are tightly folded into their tegmenal compartments. Of the 24 specimens, 13 were buried with the column intact; the remaining specimens probably also possessed stems but these have been lost, owing to weathering of the shale bank or to damage during collection. At least six specimens preserve the entire column, which terminates in a large branching root system (radix). The lengths of complete columns vary from $58 \mathrm{~mm}$ to $99 \mathrm{~mm}$, and appear to be approximately correlated with crown size. Columns are uniform in diameter throughout their length, in contrast to the tapering column figured for a specimen of Eucalyptocrinites crassus (Hall) from the Waldron Shale at Waldron, Indiana (Macurda, 1968). They are strongly heteromorphic, with deep gaps at the internodes. Distally, nodal columnals become somewhat irregular and near the root they bear small knoblike pseudocirri which appear to grade into the stout non-aligned radicular cirri at the base of the column. Root systems are well developed in these specimens and are up to $80 \mathrm{~mm}$ in diameter, composed of stiff, branched radicles. Roots did not penetrate vertically into the sediment for more than 10 or $20 \mathrm{~mm}$; rather the rootlets spread out laterally, forming a fairly broad support base for the crown and column. The initial attachment objects within these roots, if any, are unknown since the specimens were only partially extracted from the matrix. Portions of the rootlets may have been temporarily exposed at the sediment-water interface, as they appear to have been utilized as attachment substrates for rhynchonellid brachiopods.

Several Eucalyptocrinites specimens exhibit an abrupt curvature of the proximal column, which directs the crown at an angle to the column (Fig. 4B). This does not appear to have been a permanent bend, as the involved columnals are not cuneiform; rather it indicates a moderate flexibility of the proxistele. Probably this is an adaptation for turning the crown in a downcurrent direction for rheophillic feeding. Apart from the proximal quarter, the columns were quite rigid. That the columns were held vertically during life is strongly suggested by the symmetry of the root systems, by their restriction to the distal terminus of the stem, and by the symmetrical growth of epizoic favositids on the columns.

The 24 specimens exhibit a rather broad range of crown size (measured from the inflected edge of the radial plates to the base of the anal chimney) from $29.7 \mathrm{~mm}$ to $41.1 \mathrm{~mm}$ (Table 2). However, this represents only a small fraction of the total size range observed for Eucalyptocrinites caelatus specimens in other beds of the Rochester Shale (11 to more than $75 \mathrm{~mm}$ ). Furthermore, the size-frequency distribution of the 24 specimens appears to be continuous and unimodal rather than bimodal. A single generation of Eucalyptocrinites individuals is probably represented in each of the two local patches. Therefore the observed size range is thought to represent individual variation. Four of the smallest specimens $(29.7-30.7 \mathrm{~mm})$ occurred in a single clump on the large slab; stem lengths are approximately equal.

Aside from the size variation, crowns exhibit some variation with respect to ornamentation. All are pustulose to some degree, but the pustules are smaller and less closely spaced in some specimens than in others. Completely smooth specimens of $E$. caelatus have been observed in some other beds of the Rochester Shale.

Several of the Eucalyptocrinites columns bear distal coils of other crinoid stems lying between the nodal columnals. Position of the coils varies; one specimen has a 


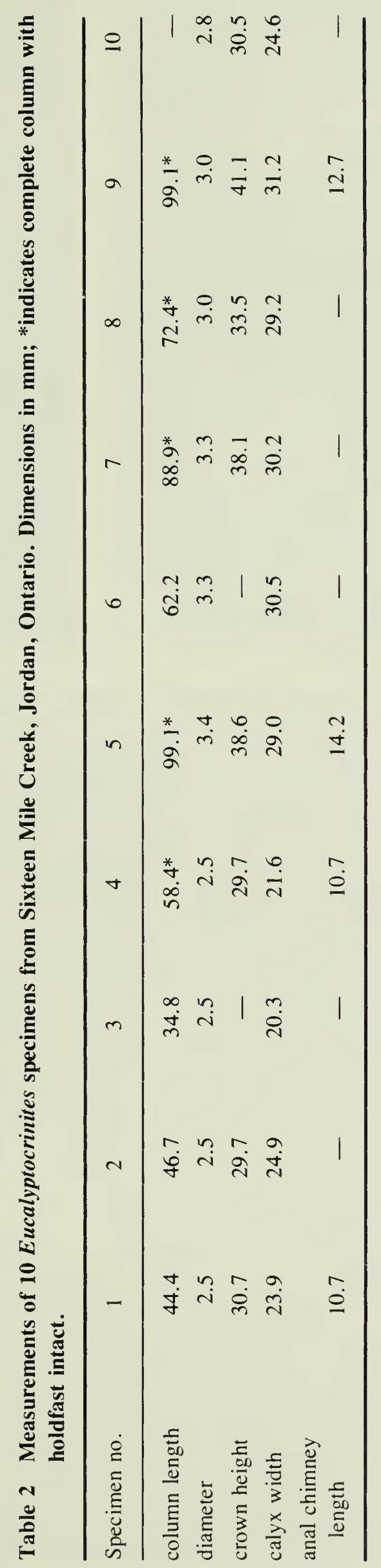


coil attached at $36 \mathrm{~mm}$ below the calyx; another has a stem loop about $10 \mathrm{~mm}$ above the root. The largest Eucalyptocrinites specimen possesses five distal coils as well as a Favosites parasiticus colony along the $99 \mathrm{~mm}$ of column. In this case the distal coils evidently belonged to Dimerocrinites since two specimens have been preserved intact with short columns and crowns outstretched on one side of the Eucalyptocrinites stem to which they are attached (Fig. 3, 4A). Four other crowns of Dimerocrinites occur in the immediate area.

This small cluster of Dimerocrinites specimens includes two species: a single 10-armed specimen identified as Dimerocrinites lilliformis (Hall), and 20-armed specimens apparently belonging to an undescribed species which also occurs in the upper member of the Rochester Shale. All specimens are relatively small compared with other Dimerocrinites from the Rochester Shale. Nevertheless there are marked differences in both calyx size and column diameter among the 20 -armed specimens. This suggests that individuals of different ages are represented in the cluster, which further implies that the crinoids settled on the Eucalyptocrinites column at different times. The clustering of five of the seven Dimerocrinites individuals on a single column among the 24 Eucalyptocrinites specimens may be related to a gregarious habit which has been observed in various dimerocrinitids and closely related ptychocrinids (Brower, 1973; Brett, 1978a).

Distal stems attached to the Eucalyptocrinites columns are very slender ( 0.5 to $1.0 \mathrm{~mm}$ ) and they taper, nearly to a point, rather than terminating on a minute holdfast pad. Columnals are cuneiform and thus attachment was permanent. There are two possible modes by which this coiling may have taken place: 1) either the free end of an initially prehensile column was actively wound around the upright Eucalyptocrinites stems, or 2) the Dimerocrinites settled at an early age and attached by a small pad; the coiling would then have been produced as the column grew by a gradual spiralling of the entire juvenile crinoid around its support rod. Of the two alternatives the latter seems less probable because of the lack of primary holdfast pads in all Rochester Shale specimens of Dimerocrinites.

Obviously, the Dimerocrinites were relatively late settlers in the crinoid colony since they attached to fully developed Eucalyptocrinites columns. The largest specimen represents a somewhat older individual, the first to settle on the Eucalyptocrinites column; smaller specimens may be slightly less mature individuals that settled later.

Fig. 4 A $-\mathrm{C}$ Details of crinoids and associated fossils.

A Enlargement of a portion of the column of ROM 35832A (see Fig. 3) showing attachment of a spherical Favosites colony and the coiled distal columns of dimerocrinitid crinoids, $\times 2.0$.

B Two crowns of Eucalyptocrinites (ROM 35832 L, M). Note well-preserved anal chimneys and abruptly curved proxistele in specimen on right $(\mathrm{M}), \times 1.1$.

C Portion of the slab showing fossils associated with the Eucalyptocrinites colony: trilobite Dalmanites limulurus (Green) (upper left), fenestellid bryozoan (centre), brachiopods Stegerynchus neglectum (Hall), and stems and crowns of Homocrinus parvus Hall (arrows), $\times 1.3$.

D Posterior view of a typical crown of Homocrinus parvus; note slender atomous arms. Lower Rochester Formation, dump piles along Welland Canal at Thorold, Ontario. ROM 39053, $\times 7.5$. 

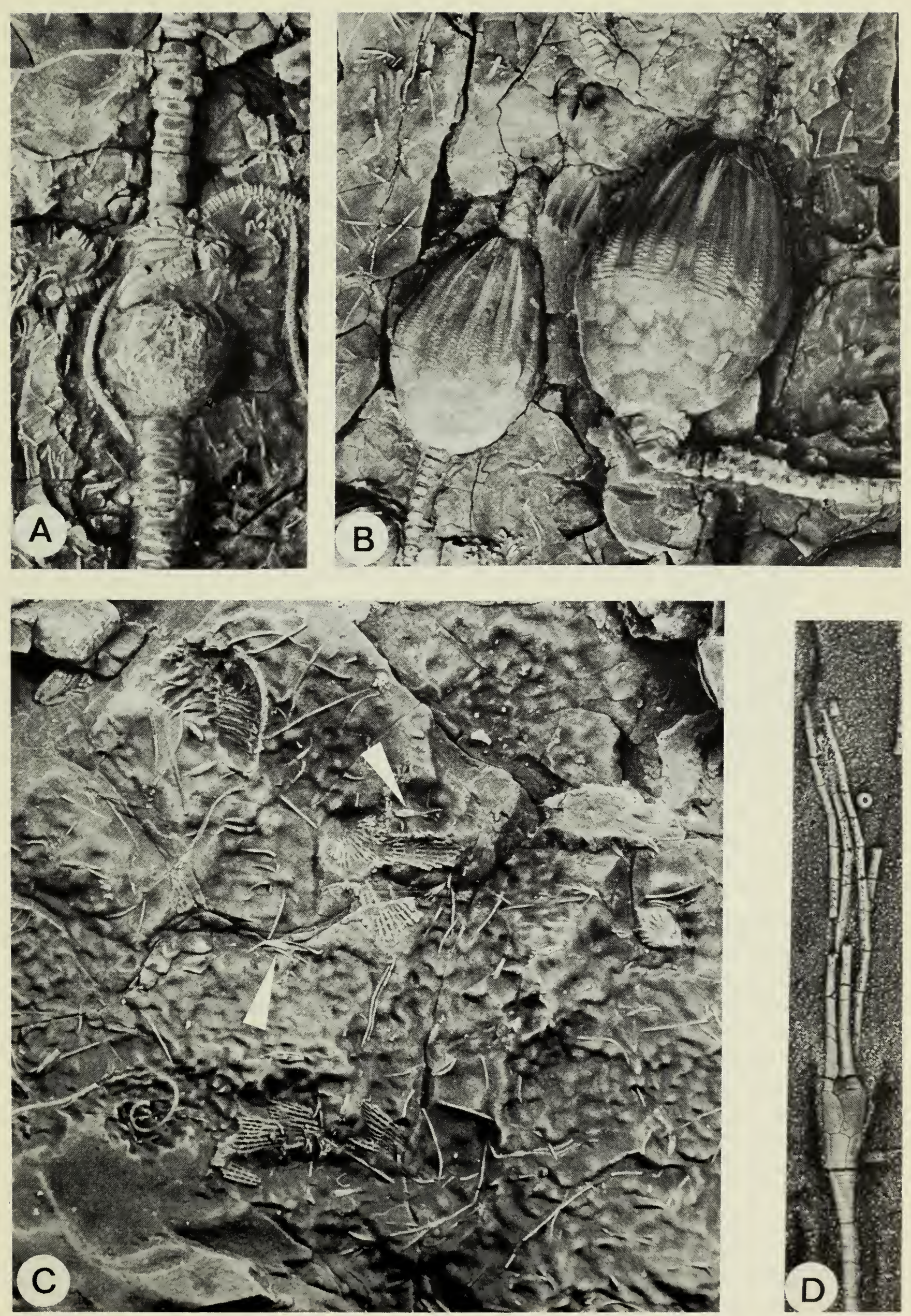


\section{Biostratinomy}

The exceptionally complete preservation of the fossil crinoids occurring in this assemblage indicates that these organisms were overwhelmed and buried alive. In a majority of the specimens there is almost no evidence of decay and disarticulation prior to entombment. In most cases, the stems of the Eucalyptocrinites were not detached from the holdfasts. Rather, the complete specimens toppled over in the living site, rotating the roots and pulling out the radicular cirri on one side as in uprooted tree stumps. Radicular cirri on the lower sides of the root system are bent backward into the sediment, as in life position, while those that were sticking upright when the specimens tipped over have been broken and pushed downward, presumably during compaction of the sediment. Thus, most of the crinoid holdfasts are in life position, though not in life orientation, having been upturned. Only in a single isolated root stump was the column facet in vertical life orientation. In addition, one complete specimen was preserved with the column broken into several segments which are telescoped in a zigzag fashion apparently onto the in situ root system. This is the only specimen in which the column is at all collapsed; the crown is also slightly collapsed and more highly compressed than any other, and has a blackish coloration while others are pink. Possibly this individual remained standing briefly after death, incipient decay then may have caused weakening of the stem and collapse into the mud.

The Eucalyptocrinites specimens on the large slab exhibit a strongly preferred orientation (Table 3). All but two of the crowns are pointed in approximately the same direction (averaging NNE: ranging from $\mathrm{N} 10 \mathrm{~W}$ to $\mathrm{N} 70 \mathrm{E}$ ). Only the remaining two specimens are oriented in the opposite direction. In one case the column is oriented perpendicularly to the crown at about $\mathrm{N} 70 \mathrm{~W}$, but in others the columns are roughly in line with the long axis of the crowns and anal chimneys. These data suggest that the majority of the Eucalyptocrinites specimens were toppled over in their life position by a surge from the south; a few individuals were uprooted by a surge from approximately the opposite direction, possibly the backwash of the same storm wave.

The Dimerocrinites specimens were evidently dragged down along with the supporting Eucalyptocrinites columns. Arms on these specimens are strongly recurved toward the calyx, an orientation also observed in numerous other specimens of dimerocrinitids. Although this could be a feeding orientation, it probably represents a death position owing to contraction of ligaments within the arms; numerous dead specimens of Recent crinoids show similar arm orientations.

Orientations of the numerous Homocrinus specimens were not measured but they appear to be more randomly tangled than the other crinoids, perhaps because of their light weight or because they became detached from their attachments. Some Homocrinus evidently settled out on top of the other crinoids because their stems are frequently draped over the Eucalyptocrinites calyces.

The two Dalmanites specimens may represent trilobites that died shortly prior to the burial of the colony. Their inverted orientation suggests a post-mortem orientation (owing to decay-gas buoyancy). Certain arthropod carapaces tend to refloat after death and settle with the ventral side upward (see Cisne, 1973, regarding trilobite orientations) 
Table 3 Orientations of Eucalyptocrinites specimens from Sixteen Mile Creek, Jordan, Ontario

\begin{tabular}{ccc}
\hline & Orientation of Calyx & Orientation of Column \\
\hline 1 & $010^{\circ}$ & $016^{\circ}$ \\
2 & 010 & 008 \\
3 & 070 & 052 \\
4 & 036 & 040 \\
5 & 030 & 290 \\
6 & 192 & 160 \\
7 & 214 & 214 \\
8 & 350 & 016 \\
9 & 054 & 350 \\
10 & 355 & telescoped \\
\hline
\end{tabular}

\section{Fossil Diagenesis}

Crinoid crowns are mainly inflated and most have been only slightly distorted. This suggests that the surrounding sediment did not undergo extensive compaction, possibly because its high carbonate content permitted early partial lithification. Similarly, inflated crinoid calyces have been observed elsewhere at the base of calcisiltite beds in the Rochester Shale. The crinoid crowns do not contain sparry calcite but are apparently all hollow, in contrast to most Rochester Shale fossils. This may also reflect early cementation and resultant low permeability of the sediment.

\section{Palaeoecology}

Evidently the major part of the Rochester sea floor in the vicinity of Jordan, Ontario, was relatively barren of skeletonized biotas. Benthic epifaunal communities occurred as small discrete patches of sessile suspension-feeding crinoids, bryozoans, and brachiopods. These clumps were surrounded by larger areas of uninhabited mud bottom.

As with many Palaeozoic epifaunal communities, the HomocrinusEucalyptocrinites assemblage exhibits height partitioning (Ausich, 1980), but unlike most such examples, the lower tier of suspension feeders-those living at the sediment-water interface-is poorly de veloped. With stem lengths exceeding $100 \mathrm{~mm}$, mature individuals of Homocrinus parvus evidently fed at higher levels than any of the associated (much larger) Eucalyptocrinites.

Homocrinus probably carpeted fairly large areas of the sea bottom and was numerically the dominant epifaunal organism. Evidence from other outcrops proves that these minute inadunates occurred in areas not populated by most other crinoid species. 
In the Homocrinus band of the lower Rochester Shale at Lockport, New York, Homocrinus specimens are abundant on certain bedding planes which are otherwise nearly barren of fossils (Ringueberg, 1888). We have also observed specimens of this crinoid in sparsely fossiliferous shales and calcisiltites at several other localities. Sedimentological and taphonomic evidence suggests that these crinoids were adapted to low energy mud bottoms tolerated by relatively few other organisms (Brett, 1978c).

Eucalyptocrinites represents the next lowest level of suspension feeders, with crowns elevated 60 to $80 \mathrm{~mm}$ above the sea bottom. These crinoids were probably the largest sessile organisms on this portion of the sea floor, and, as such, they were colonized by other epifauna including favositid corals, brachiopods, and other crinoids. Such organisms occupied various levels above the substrate: rhynchonellid brachiopods probably attached near the base of the crinoid stems at the sediment-water interface, favositids occurred 10 to $20 \mathrm{~mm}$ above the bottom, and dimerocrinitids may have fed at about the same level as Eucalyptocrinites. Finally, a few isolated fenestrate and ramose bryozoans occupied an intermediate height 5 to $30 \mathrm{~mm}$ above the substrate.

The occurrence of tabulates and brachiopods only a few millimetres above the sediment-water interface indicates that the water immediately above the substrate was well-oxygenated and contained abundant food resources, favourable for the existence of relatively sensitive suspension feeders. Nevertheless, very few organisms lived directly on the sea bottom. In contrast to most Rochester Shale assemblages, even the nearly ubiquitous brachiopods such as Striispirifer and Strophonella are absent here. This paucity of low-level suspension feeders may reflect the unsuitable nature of the substrate or a high rate sedimentation, or both.

Nodose outgrowths on the distal columnals of many Eucalyptocrinites specimens probably represent incipient radicles. Evidence from other fossil crinoids suggests that the formation of such outgrowths is stimulated by contact of the epidermis with the substrate (Halleck, 1973; Brett, 1978b, c). If so, the height of the outgrowths above the base of the stem can be taken as an indicator of the amount of sediment that accumulated during the lifetime of the crinoid. In most specimens of Eucalyptocrinites from these colonies the uppermost nodal outgrowths occur 10 to $20 \mathrm{~mm}$ above the base of the stem. This also corresponds to the lowest level of attachment of dimerocrinitid distal coils and on the largest specimens the favositid corals occur only slightly above this area of the stem. Analogy with modern crinoids suggests that the maximum life span of Eucalyptocrinites was probably 10 to 20 years (Fell, 1966). Furthermore, these specimens are only about half the size of the largest specimens of Eucalyptocrinites from the Rochester Shale; they were probably killed well before reaching their full life span. Thus one might infer a minimal sedimentation rate of about $10 \mathrm{~mm}$ in 3 years. Obviously, much more rapid sedimentation rates occurred sporadically, as during the burial of the colony when 20 to $30 \mathrm{~mm}$ of mud probably accumulated within a few hours. The ease with which the crinoids were uprooted indicates that the bottom sediment consisted of unconsolidated mud at the time of burial.

Larvae of benthic invertebrates were probably being constantly supplied to this area from adjacent, more favourable bordering regions. For example, abundant bryozoan-brachiopod-echinoderm assemblages are present in the lower Rochester 
Shale at Balls Falls only $3 \mathrm{~km}$ to the northwest. However, successful colonization of the sea floor by these organisms was normally inhibited both by the substrate consistency and the related high rate of siltation.

Development of local patch communities on this sea bottom probably reflects a minor break in sedimentation during which certain of the recruited larvae were able to mature.

Eucalyptocrinites roots from other outcrops are known to have been attached initially to solid objects, such as brachiopod shells (Halleck, 1973). The same is probably also true of the Sixteen Mile Creek specimens. However, none of the root specimens could be spared for sectioning without damaging the slab assemblage. Secondary development of radicles facilitated support and anchorage of the relatively large crinoids on the mud substrate.

Similarly, Homocrinus and bryozoans are thought to have initially settled on small hard substrates. A few fragments of crinoid plates and bryozoans were found in association with the well-preserved crinoids and such hard fragments may have permitted initial colonization of the mud bottom.

Crinoids may have been able to survive to adulthood because of rather rapid early stem growth which raised the crowns above the sea bottom to a sufficient height to prevent smothering. In contrast, other organisms, such as brachiopods, were unable to survive the mud because of their much slower elevation off the bottom.

\section{Discussion}

Well-preserved assemblages of fossil pelmatozoans almost invariably indicate rapid death of living associations followed by anastrophic burial. One would predict that conditions favourable to such rapid burial events would recur more frequently (in a geological sense) in certain depositional environments than others. Recurrence of mass mortalities in localized stratigraphic sections (e.g., the three successive smothered bottom assemblages in the $2 \mathrm{~m}$ interval at Sixteen Mile Creek) strongly suggests that this is the case. Conditions favouring this type of catastrophic burial appear to exist most frequently in muddy-bottomed biotopes below normal wave base, but within storm wave base. In such areas there is a readily available supply of fine-grained sediment, which can be resuspended and deposited rapidly. The sea floor is shallow enough to be affected by the scouring of storm waves but deep enough to remain undisturbed for long time spans. Consequently, organic remains, once buried, are unlikely to be exhumed and reworked, except by biogenic processes.

Low-energy conditions also tend to promote anoxia in the upper layers of the sediment which, in turn, may inhibit bioturbation. In higher-energy, shallower enviroments, rapid destruction and burial of pelmatozoan assemblages may occur even more frequently, but the probability of reworking of the buried remains is also high. Therefore few such assemblages remain intact (Ruhrmann, 1971; Hagdorn, 1978). On the other hand, deep, quiet-water environments tend to be stable, undisturbed areas where rapid burial of assemblages will almost never occur. 
Thus, many of the best-preserved and, therefore, best-studied fossil pelmatozoan assemblages represent associations of pelmatozoans adapted to a particular range of marine biotopes (moderately shallow, but below normal wave base, level muddy bottoms) and the full range of pelmatozoan habitats is not equally represented in the fossil record. The taxonomic similarity of many of the best-preserved echinoderm fossil assemblages indicates that these represent a distinctive ecologically controlled association type. Such mass mortality occurrences are characterized by a high dominance of a few species. Presumably these represent atypical taxa which were tolerant of low energy, rather muddy areas (rheophobes, in the terminology of Breimer, 1969). Large fossil crinoid assemblages are typically associated with few other fossils, indicating a paucity of "normal" low-level suspension feeding organisms in the original communities. Previous authors (Lane, 1963; Frest and Strimple, 1978) have suggested that a dense crinoid "overstory" produces a baffling effect such that there is less available food for lower lying organisms. However, the density of crinoids required to "shade" large areas of sea floor would seemingly be of an order of magnitude greater than that observed in most fossil crinoid colonies. Furthermore, even slight water currents would tend to move planktonic food particles laterally rather than vertically, thus eliminating the "shadow effect".

We suggest that the occurrence of fossil crinoid colonies in otherwise sparsely fossiliferous strata may be largely an artifact of selective preservation. Conditions which favour good preservation of fossil echinoderms (i.e., rapid sedimentation of fine-grained sedimentation followed by low energy conditions) tend to be the same factors that also deter colonization of the sea floor by most organisms-including many crinoids. The obvious implication of this taphonomic bias for palaeontology is that the best palaeoecological data has been obtained for those crinoid species that are adapted to marginal habitats; in effect, for only a few "opportunistic' species. Nonetheless, inferences derived from such occurrences may be used to interpret other less well-preserved crinoid assemblages.

\section{Acknowledgements}

We wish to thank D. Bradford Macurda, Jr., Bruce H. Wilkinson, and John Dorr for critically reviewing this manuscript and suggesting improvements. Desmond Collins and Peter von Bitter permitted use of preparation facilities at the Royal Ontario Museum. 


\section{Literature Cited}

AUSICH, W.I.

1980 A model for niche differentiation in Lower Mississippian crinoid communities. Journal of Paleontology 54:273-288.

BOLTON, T.E.

1957 Silurian stratigraphy of the Niagara Escarpment in Ontario. Geological Survey of Canada, Memoir 289:1-145.

BREIMER, A

1969 A contribution to the paleoecology of Paleozoic stalked crinoids. Koninklijke Nederlandse Akademie van Wetenschappen, Proceedings, Ser. B, 72:139-150.

BRETT, C.E.

1978a Description and paleoecology of a new Lower Silurian camerate crinoid. Journal of Paleontology 52:91-103.

1978b Attachment structures in the rhombiferan cystoid Caryocrinites, and their paleobiological implications. Journal of Paleontology 52:717-726.

1978c Systematics and paleoecology of Late Silurian (Wenlockian) pelmatozoan echinoderms from western New York and Ontario. Ph.D. Thesis, University of Michigan. 613 pp.

BROWER, J.C.

1973 Crinoids from the Girardeau Limestone (Ordovician). Palaeontographica Americana 7:263-499.

CISNE, J.L.

1973 Beecher's trilobite bed revisited: ecology of an Ordovician deep-water fauna. Postilla 160:9-34.

FELL, H.B.

1966 Ecology of crinoids. In Boolootian, R.A., ed., Physiology of Echinodermata. New York, Wiley Interscience, pp. 49-62.

FREST, T.J. and H.L. STRIMPLE

1978 Manicrinus (nov.), a cladid evolutionary homeomorph of the bottom-dwelling Hybocrinus, Brownsport (Silurian: Ludlow) of Tennessee. Southeastern Geology 19:157-175.

GRABAU, A.W

1901 Guide to the geology and paleontology of Niagara Falls and vicinity. Buffalo Society of Natural Sciences Bulletin 1:1-284.

HAGDORN, H.

1978 Muschel/Krinoiden Bioherme im Oberen Muschelkalk (mol. Anis) von Crailsheim und Schwäbisch Hall (Südwestdeutschland). Neues Jahrbuch für Geologie und Paläontologie, Abhandlungen 156:31-86.

HALL, J.

1852 Descriptions of the organic remains of the lower middle division of the New York System. Paleontology of New York, vol. 2. Albany. 362 pp.

1881 Description of the species of fossils in the Niagara Group at Waldron, Indiana. Indiana Department of Geology and Natural History, 1 lth Annual Report, pp. 217 -345.

HALLECK, M.S.

1973 Crinoids, hardgrounds, and community succession: the Silurian Laurel-Waldron contact in southern Indiana. Lethaia 6:239-251. 
1977 The poor fossil record of the regular echinoid. Paleobiology 3:168-174.

LANE, N.G.

1963 The Berkeley crinoid collection from Crawfordsville, Indiana. Journal of Paleontology 37: 1001-1008.

1972 Synecology of Middle Mississippian (Carboniferous) crinoid communities in Indiana. 24th International Geological Congress, Montreal, 1972, Section 7, pp. 89-94.

1973 Paleontology and paleoecology of the Crawfordsville fossil site (upper Osagian, Indiana). University of California Publications in Geological Sciences 99:1-141.

LIDDELL, W.D.

1975 Recent crinoid biostratinomy. Geological Society of America, Abstracts with Programs 7:1169.

MACURDA, D.B., Jr.

1968 Ontogeny of the camerate crinoid Eucalyptocrinites. In Macurda, D.B., Jr., ed., Paleobiological aspects of growth and development: a symposium. Paleontological Society Memoir 2:99-118.

MEYER, D.L.

1971 Post-mortem disarticulation of Recent crinoids and ophiuroids under natural conditions. Geological Society of America, Abstracts with Programs 3:645.

RICHARDS, R.P.

1972 Autecology of Richmondian brachiopods (Late Ordovician of Indiana and Ohio). Journal of Paleontology 46:386-405.

RINGLEBERG, E.N.S.

1888 The Niagara shales of western New York; a study of their origin and of their subdivisions and their faunae. American Geologist 1:264-272.

ROSENKRANZ, D

1971 Zur Sedimentologie und Ökologie von Echinodermen-Lagerstätten. Neues Jahrbuch für Geologie und Paläontologie, Abhandlungen 138:221-258.

RUHRMANN, G.

1971 Riff-nahe Sedimentation paläozoischer Krinoiden-Fragmente. Neues Jahrbuch für Geologie und Paläontologie, Abhandlungen 138:56-100.

SEILACHER, A

1970 Begriff und Bedeutung der Fossil-Lagerstätten. Neues Jahrbuch für Geologie und Paläontologie, Monatshefte 1970:34-39. 



ISBN 0-88854-281-X ISSN 0384-8159 